\title{
Article \\ Inclusion as Ethics, Equity and/or Human Rights? Spotlighting School Mathematics Practices in Scotland and Globally
}

\author{
Dalene M. Swanson ${ }^{1, *}$, Hong-Lin $\mathrm{Yu}^{2}$ and Stella Mouroutsou ${ }^{1}$ \\ ${ }^{1}$ Faculty of Social Sciences, University of Stirling, Stirling, FK9 4LA, UK; E-Mails: dalene.swanson@stir.ac.uk (D.M.S.), \\ stella.mouroutsou@stir.ac.uk (S.M.) \\ ${ }^{2}$ Faculty of Arts and Humanities, University of Stirling, Stirling, FK9 4LA, UK; E-Mail: h.l.yu@stir.ac.uk \\ * Corresponding author
}

Submitted: 4 April 2017 | Accepted: 23 August 2017 | Published: 26 September 2017

\begin{abstract}
Mathematics education has been notoriously slow at interpreting inclusion in ways that are not divisive. Dominant views of educational inclusion in school mathematics classrooms have been shaped by social constructions of ability. These particularly indelible constructions derive from the perceived hierarchical nature of mathematics and the naturalised assumption that mathematisation is purely an intellectual exercise. Constructions of ability, therefore, emanate from the epistemic structures of mathematics education as predominantly practiced worldwide, and the prevalence of proceduralism and exclusion in those practices. Assumptions about 'ability' have become a truth to mathematical aptitude held by mathematics teachers in schools. This includes schools across Scotland. In Scotland, the government owes the 'included pupil' a legal obligation to provide additional support for learning under section 1(1) of the Education (Additional Support for Learning) (Scotland) Act 2004. However, classroom practices deployed around socially-constructed notions of ability have seen schools moving away from an emphasis on 'additional' to an expansive interpretation of 'different from' in the language of section 1(3)(a) of the Act 2004. This shift, therefore, reinstalls exclusionary effects to school mathematics practices by creating the conditions for some pupils, constructed in terms of disabilities or low ability, to be afforded a more inferior education than others. While philosophical conversations around whether these practices are ethical, egalitarian or democratic might ensue, there is also the human rights angle, which asks whether such practices are even lawful.
\end{abstract}

\section{Keywords}

ability; Additional Support Needs; classroom practices; education; equality; equity, inclusion, law; mathematics; policy; school; social construction; streaming

\section{Issue}

This article is part of the issue "Promoting Children's Participation in Research, Policy and Practice", edited by Jo Aldridge (Loughborough University, UK).

(C) 2017 by the authors; licensee Cogitatio (Lisbon, Portugal). This article is licensed under a Creative Commons Attribution 4.0 International License (CC BY).

\section{Introduction}

In 1994, 92 countries and 25 international organisations signed up to the Salamanca Statement and Framework for Action on Special Needs Education (UNESCO, 1994). This heralded in a new era of policy-driven mandates worldwide, placing emphasis on inclusion within schools and societal institutions. Inclusion policies became mandatory within schools across many parts of the minority and majority world. In Scotland, Curriculum for Excellence (CfE) has embraced inclusion and rightsbased discourses, applying it to its progressive branding. This has been reflected in the move from Special Educational Needs (SEN) to Additional Support Needs (ASN), shifting the emphasis away from integration and equity, following the Warnock Report (Department of Education and Science, 1978), to one of increased participation and removal of barriers to inclusion (Allan, 2003). 
This latter emphasis meant compensation for any disadvantage a learner's disability might create within mainstream schooling by offering additional resources. But, it also meant shifting the culture of schools and societal institutions to more 'inclusive' orientations. The school was to benefit from extra resources aimed at supporting teachers in accommodating the 'needs' of the pupil requiring ASN. Moving away from terminology such as 'impairment', this meant normalising disabilities as measures of natural diversity within society at large. While a 'medical model' approach is still highly prevalent, a more 'social model' has emerged. This has begun to shift the 'burden of representation' (Tagg, 1988; Swanson, 2004) of disability, as dominantly-conceived within a deficit/defectology mode of disability framing, from the individual designated as disabled, to the responsibility of society as a whole (Goodley, 2004, 2013; Valle \& Connor, 2010).

In the UK, despite the greater emphasis on inclusion within schools, practices have often lagged behind policy, and there has been slippage in interpretations of intentions, or how to meet those inclusion objectives (Allan, 2008; Mouroutsou, 2017). In some instances, the 'inclusion objectives' themselves can be held up for scrutiny in terms of the assumptions they make about disability, inclusion, what constitutes 'normal', and the nature of childhood (Harwood \& Allan, 2014). Arguably, a language of 'needs' may also be exacerbating the difficulty, by ensuring the element of patronage attends approaches to inclusion (Swanson, 2004). While these issues pertain variously to subjects across the curriculum, school mathematics education has been notoriously slow at interpreting 'inclusion' in ways that are not divisive. This can be witnessed in the prevalence of differentiated and distributed practices built around an indelible, socially-constructed notion of ability (Dowling, 1991; Swanson, 1998, 2005). Constructions of ability emanate from the epistemic structures of mathematics education as prevalently practiced worldwide, and the predominantly procedural and exclusionary nature of those practices. Consequently, assumptions held by mathematics teachers in schools about 'ability' as a truth to mathematical aptitude abound (Zevenbergen, 2001, 2003; Tytler, Swanson, \& Appelbaum, 2015), including those across Scotland.

In Scotland, the government owes the included pupil' a legal obligation to provide additional support for learning under section 1(1) of the Education (Additional Support for Learning) (Scotland) Act 2004. However, classroom practices deployed around sociallyconstructed notions of ability have seen schools moving away from an emphasis of 'additional' to an expansive interpretation of 'different from' in the language of section 1(3)(a) of the Act. This has reinstalled exclusionary and inequality effects to the practices by creating the conditions for some pupils, constructed in terms of disabilities or 'low ability', to be afforded a more inferior educational experience than others. This is the case, even as it is being asserted as inclusive and equitable under the discursive banner of 'special support'. While philosophical conversations around whether these practices are ethical, egalitarian or democratic might ensue, there is also the human rights angle, which asks whether these practices are even lawful.

This article addresses the issue of inclusion through a rights-based lens in respect of school mathematics education. While it discusses the conversations on equity, ability, democracy and inclusion within the international mathematics education field, it focusses on what these implications might be in relation to particular practices within the Scottish policy context. It consequently also draws attention to the contribution this makes to the international mathematics education field in respect of inclusion, social justice and rights-based pedagogical practices in mathematics classrooms. The arguments in this paper draw on, but also exceed, the conversations taking place in the field of mathematics education. They do so by moving beyond ethics and egalitarianism, which has been a strong focus of critical mathematics education recently (Ernest, Sriraman, \& Ernest, 2016; Swanson, 2017; Stinson, 2017). Rather, they more directly attend to these issues in relation to rights and the implications for understandings of inclusion. These are prismed through the lens of policy mandates and legal frameworks, from which one might scrutinise prevailing practices and interpretations of policy in school mathematics contexts.

The article proceeds by first addressing mathematics and mathematics education in terms of its hidden values and the politics of meaning around de/mathematisation (Chronaki \& Swanson, 2017; Gellert \& Jablonka, 2007) in the context of constructions of ability, failure, and disadvantage. But, it also calls for equality, ethics, and a more critical relationship with democracy in respect of mathematics education practices (Skovsmose \& Valero, 2001; Swanson, 2017). It frames the discussions by offering some sense of the conversations with these emphases within the mathematics education field. These discussions fall under the following headings: 2) School mathematics and the politics of meaning. This leads onto discussion of the policy agenda on inclusion: 3) School mathematics, inequality, and policies of inclusion, which then opens to a focus specifically on Scotland in policy context: 4) Mathematics education and inclusion in Scotland. This segues into a centering of discussions from a more legal framework perspective, incorporating a strongly child rights-based approach to mathematics education in Scotland. This discussion takes place under a banner of: 5) Mathematics education, inclusion, and the Law. Concluding remarks tie structural inequalities in mathematics education together with inclusion and the Law. This approach is embraced in order to frame an international research agenda around the question of whether certain disability practices of inclusion in mathematics classrooms are more than a question of ethics and inequity, or if they are even lawful. 


\section{School Mathematics and the Politics of Meaning}

Mathematics has dominantly been touted as an objective subject (Davis \& Hersh, 1986; Swanson, 2005), one which is apolitical, dispassionate, and where human values are considered irrelevant. It has been viewed as the discipline that preceded humans, mapped into the cosmos, and, for Galileo Galilei, the language with which God wrote the universe, according to his now famous quote (Collins, 2006). So divorced has mathematics been perceived as being from the human condition that Giovanni Batista Vico (1668-1744), an Italian philosopher, lawyer, and classicist, was known to have stated that "mathematics is created in the self-alienation of the human spirit. The spirit cannot discover itself in mathematics. The human spirit lives in human institutions" (quoted in Davis \& Hersh, 1986, p. x). This has not been isolated to mathematics, but school mathematics education has inherited to large degree these values and perceptions as its logic of schooling (Bishop, 2008).

One of the most notorious, commonly-held fallacies about school mathematics, following its 'master discipline', is that it is a neutral subject, one which is detached from the pesky political machinations of society and its trying subjectivities (Davis, 2013; Ernest et al., 2016; Swanson, 2005). There is the sense, like Mathematics itself, that school mathematics is not underpinned by any social or cultural values, and that it is a subject that is ahistorical and non-ideological. The ways in which it is shaped by societal influences, such as social inequality, is therefore dominantly viewed as external to school mathematics itself and can be explained almost entirely by economic forces such as scarcity and access to schooling, finance and other resources. Internal structural elements within school mathematics discourses and practices remain largely hidden within the social domain as a result (Bishop, 2008; Ernest et al., 2016; Swanson, 2005). Referencing these effects on mathematics education, Skovsmose and Valero (2001), in drawing on Skovsmose's previous work, remark: "Mathematics has a power that escapes the boundaries of rationality and argumentation, and, through its applications, it has become one of the forces of social reflexive modernization" (p. 41).

Nevertheless, debates on school mathematics education effects have dominantly been framed in relation to 'the attainment gap' or differentiated achievement in schools, which largely mirrors socioeconomic inequality in society (Atweh, Forgasz, \& Nebres, 2001; Dowling, 1998; Swanson, 2005). Highly class-driven societies, such as that of the United Kingdom (UK), often display a range of achievement levels in school mathematics that reflect regional, gender, racial, cultural, linguistic, ethnic, socioeconomic and other demographic differences (Gates \& Jörgensen, 2009; Skovsmose \& Valero, 2001; Swanson, 1998; Walkerdine, 2012). In fact, these correspondences appear to be so marked that socioeconomicrelated differences and societal marginalisation can be prismed through the lens of access to school mathe- matics and achievement levels. Mathematics education research has responded to this 'critical relationship to democracy' (Skovsmose \& Valero, 2001) in a number of ways and areas of research focus. There has been extensive research from many parts of the world, both majority and minority world contexts, reflecting on a troubling relationship between student demographics and access to the discourse and practice of mathematics education in schools (Skovsmose \& Valero, 2001; Swanson, 2004, 2005; Walkerdine, 2012; Zevenbergen, 2003). This has been evidenced in prominent 'equity and access' agendas internationally (Atweh, Rossi Becker, Grevholm, \& Subramanian, 2016; Atweh \& Swanson, 2016) within the field of mathematics education over several decades, and looms large in a focus on mathematics education and socioeconomic status (Lubienski \& Lubienski, 2005; Perry \& McConney, 2010) or 'disadvantage' (Swanson, 1998, 2005), as well as conversations on mathematics education and democracy (Skovsmose \& Valero, 2001; Vithal, 2010).

Socio-political discourses within the field of mathematics education (Valero \& Zevenbergen, 2004) are relatively new. They often critically attend, amongst other noted concerns, to issues such as the alarmist discourses that abound warning of the detrimental effect to economies of national failure rates in mathematics education (Ernest et al., 2016; Swanson, 2013). In these discussions, it is acknowledged that mathematics education has often been used by nation states to pit their populations against each other in international competitions such as Programme for International Student Assessment (PISA), the National Assessment of Educational Progress (NAEP) in the USA, or the repeat of the Third International Mathematics and Science Study (TIMSS-R), sending signals of 'crisis' with respect to mathematics education and national interests, security and economics (OECD, 2016; Perry \& McConney, 2010). This economic development functionalist perspective has been the dominant view in international and national conversations on mathematics education. The fixations with these perspectives within an era of what is often framed as globalising neoliberal governmentality (Foucault, 2004; Larner, 2000; Lemke, 2001; Ferguson \& Gupta, 2002) is reflected in the (inter)national advocacies of 'numeracy' and 'literacy' in schools, and in the broader promotion of Science, Technology, Engineering and Mathematics (STEM) subjects worldwide. In this mode, Education ministries in countries across the world push the STEM agenda in the hopes of their countries' gaining competitive economic advantage over their national rivals (Swanson, 2017; Tytler et al., 2015).

While economic and political utilitarian agendas have attended school mathematics education within nation states, and while some research emphasis has been given to these functionalist agendas, the question of ethics has been a relatively recent contribution (Maheux, Swanson, \& Khan, 2012; Stinson, 2017). Relational and reflexive aspects of mathematics learning in schools have 
at their core concerns about equality, respect, difference, and democratic responsibility. These ethical considerations require taking into account issues, not only of equality, relationality, intersubjectivity, relations of power, and democracy within school mathematics educational contexts, but also of the concept of 'inclusion' (Figueiras, Healy, \& Skovsmose, 2016). How inclusion is conceptually deployed beyond policy mandates to better consider the dilemmas constituted as a result of slippage between policy and practice is of deeper concern to mathematics education in relation to an agenda of equality.

In particular, Figueiras et al. (2016) offer a critique of the notion of 'inclusion' in its appropriation in mathematics education. For them, inclusion begs the question of inclusion into what? This question is used to theorise on the 'formatting power of mathematics' (Skovsmose, 1994; Skovsmose \& Yasukawa, 2004). This is the idea that mathematics has within its structures particular values that, through exposition in classrooms, carry a set of hidden agendas. The performance of these structural formatting codes in classrooms serves to recruit or interpellate (Althusser, 1971) the learner into a particular, differential subjectivity in relation to mathematics, which can be viewed as ideological.

Other theorists have drawn on Ngũgi wa Thiong'o's (1986) notion of 'colonisation of the mind' to describe this effect within mathematics education, also argued in its political and psycho-social effect as acting as a form of "occupation of the mind" (Khuzwayo, 1998). Swanson and Appelbaum (2012) take this further to ask whether the right to refuse the colonising power of mathematics is not in itself an act of 'radical democracy' (Rancière, 2009) at work. This provides a sense of the politics of values and meaning within mathematics education conversations. There is, therefore, a sense of grappling with what social justice (Gutstein, 2006) might mean for school mathematics informed by policy and practice.

Nevertheless, when examining the issues of rights and duties with respect to mathematics education, it is necessary to understand and attend to the many microexclusions that take place in mathematics classrooms and schools even as macro-inclusions of mathematics education are supported by policy-wide mandates and calls for widening participation in the subject. This seemingly paradoxical situation needs to be given due consideration, especially given the power of effect such micro and macro exclusions have on individuals and communities lives as a result of the 'strong voice' (Bernstein, 2000; Dowling, 1998) of mathematics in schools and the social domain. Understanding how schools and classrooms are governed by inclusion policies is necessary in analysing how school mathematics hierarchies in these contexts respond. Since school mathematics is a highly 'vertical discourse' (Bernstein, 2000) with its internal hierarchies of power, it is more difficult than other subjects that are more 'horizontal' (Bernstein, 2000) to address the rights of equality of access and treatment accorded by educational inclusion policy. The policy framework we draw on for purposes of discussion and exemplification is the Scottish one, a context within which the authors operate as educators, lawyers, and academics.

\section{School Mathematics, Inequality, and Policies of Inclusion}

The inclusion of all children in mainstream schools is a key educational policy across Europe. In Scotland, there is a raft of acts and policies promoting inclusion of all children in the mainstream. The Standards in Scotland's Schools etc. (Scotland) Act 2000, enshrines the principle of the Salamanca Statement. This statement asserts that "...schools should accommodate all children regardless of their physical, intellectual, social, emotional, linguistic or other conditions" (UNESCO, 1994, p. 6). It introduces the presumption of mainstreaming, establishing the idea that all children should be educated in their local school unless specific circumstances arise. The circumstances are:

...to provide education for the child in a school other than a special school (1) would not be suited to the ability or aptitude of the child; (2) would be incompatible with the provision of efficient education for the children with whom the child would be educated; or (3) would result in unreasonable public expenditure being incurred which would not ordinarily be incurred. (Standards in Scotland's Schools etc. (Scotland) Act 2000, p. 7)

The Standards in Scotland's Schools etc. Act 2000 was followed by the Education (Additional Support for Learning) (Scotland) Act 2004, (ASL), which introduced the discourse of 'additional support needs' (ASN) and replaced 'special educational needs' (or SEN) so referred in the 1980 Act. This was done with the purpose of de-stigmatising, and while controversy reigns regarding which approach to adopt in addressing disability, destigmatisation is an ethical imperative to which most agree within the disability field (Watson, 2012). This means that all children and young people may require additional support at some stage during their school career, and local authorities and other agencies have the duty to provide additional support where needed. This denotes a move from 'special needs' to 'learning for all'. Following its amendment, the Education (ASL) (Scotland) Act 2009 provides some clarification regarding the rights of children with ASN.

The UK's Equality Act 2010 also supports inclusive education in Scotland and provides a single source of discrimination law, including all the unlawful types of discrimination, thereby promoting equity. Additionally, A Guide to Getting It Right for Every Child (Scottish Government, 2008) and the Children and Young People (Scotland) Act 2014 serve to promote inclusion in Scotland. Particularly, in Scotland, there is a shift not only in the language used, but in the conceptualisation of inclusion 
too, as now there is an emphasis on provision of support with a focus on the right of every child to education. Nevertheless, the promotion of inclusion through Scottish policy and legislation is not automatically translated into adoption of inclusive practices in schools (Allan, 2008; Mouroutsou, 2017). Several tensions and difficulties exist associated with the way in which the policies that promote inclusion are interpreted and implemented in schools. Several commentators reference this critically in the light of difficulties associated with a continued adherence to a discourse of 'individual needs' with little development of a rights discourse more broadly (Riddell, 2009).

\section{Mathematics Education and Inclusion in Scotland}

In PISA 2015, Scotland's scores in the three areas, including mathematics, were lower than in previous PISA surveys (Scottish Government, 2016). Nevertheless, this does not necessarily mean there is something amiss with Scottish schooling per se, and PISA tests are not based on any specific school curricula tasks. Their aim to measure 'abilities' beyond the school curriculum are therefore problematic in making judgements about schooling systems and curricula more widely. As asserted earlier, there is arguably too much emphasis placed on these international testing regimes, which are reductive in their approach to conversations that wish to address issues of inequality and democracy in schooling at a structural level. In fact, correspondences are made that are based on too broad a set of generalisations in coming to understand what influences inequality, underachievement, or 'failure' in schools. These causality discourses often become social constructions in themselves in the ways they are applied to particular judgements that bear political consequences and effect (Swanson, 1998, 2004, 2005). Often, international comparative tests place ministries of Education under pressure to act impulsively by applying a 'tick box' approach in aiming to correct perceived failing. They often create unrealistic pressure on ministries to institute a raft of autocratic measures to which schools are compelled to comply. This is exacerbated by media-hype around constructed 'crisis'. This may well incapacitate what might be a well-functioning schooling system by becoming governed by constant states of crisis, thereby installing a modernist ideology of ongoing 'crisis' as its modus operandus. By contemplating reform to curriculum policy too quickly, there is the danger of deflecting emphasis away from deeper structural, social and educational issues that have little to do with international educational competitions and their testing regimes other than this standardising, monitoring approach exacerbating them. Nevertheless, a telling finding from the most recent PISA results is that Scottish students were more likely than other nations' students to be grouped by ability into different classes and within classes (National Foundation For Educational Research, 2016).
Constructions of ability and practices that constitute them, based on conceptions of the learner and their background, have particularly deleterious effects on learners and classrooms. They install ideologies of elitism, disadvantage and exclusion (Bishop \& Kalogeropoulos, 2015). The risks are well rehearsed in the literature, which speaks of how these ability constructions open up practices that enable constructions of failure (Sullivan, Zevenbergen, \& Mousley, 2002; Swanson, 2004). A social class structure emerges from grouping by ability, producing a self-fulfilling prophecy and dialectic between the 'can's' and 'cant's' of school mathematics (Dengate \& Lerman, 1995; Zevenbergen, 2001, 2003; Swanson, 2005). In two studies, Swanson (1998, 2004) analyses the critical relationship between the ways in which a group of students, constructed in terms of race, ethnicity, culture, language difference, and poverty, came to be positioned in terms of further deficit labels and constructions of disability through various performances of school mathematics discourses and practices. This occurred in ways that were structurally-informed by the differentiating codes and rituals of school context (Bernstein, 2000). In this way, constructed disadvantage worked to produce pedagogic disadvantage, acting to prevent these students from access to the 'regulating principles' (Bernstein, 2000) of school mathematics, and hence also to positions of 'success' through instruments of assessment. Drawing on the work of Dowling (1998) and Bernstein (2000), the interrelated concepts of context, power, discourse, subjectivity, and ideology worked together to reveal how disadvantage was constructed and reproduced within mathematics classrooms, affording possibilities and advantages to some and not others. Bernstein's (2000) concepts of 'recognition rules/codes' and 'realisation rules/codes' that affect success and failure in schools, and that produce various subject positions for learners from 'affirmation' to 'alienation', helped in providing a framework for analysis. Bernstein's concepts of 'classification' and 'framing', which speak to issues of power within and between school mathematics with its strong voice (Bernstein, 2000; Dowling, 1998), also formed an important part of the conceptual framework. These analytical categories provided a complex framework for sociological description of how disadvantage is (re)produced, but the research projects and theorisations on constructed disadvantage also allowed for analysis of tensions, resistances, and possibilities.

As it has been argued by Jörgensen, Gates and Roper (2014), school mathematics gives emphasis to inequality within the education system that then lends itself to social segregation. Ability grouping and other practices can have exclusionary effects by creating conditions for some pupils, constructed in terms of disabilities or low ability, to be afforded a more inferior education than others. These constructions beget further constructions that reinforce deficit perspectives. Rather than receiving an enriched, engaging mathematics education, learners deemed 'low ability', 'slow', or 'disabled', most often 
receive an impoverished mathematics education (Swanson, 2004) that then acts as a barrier to future possibilities, advancement and wellbeing. This goes against one of the key social purposes of education, to improve life opportunities, by acting instead to reduce them (Davis, 2013). The 'additional support' is reduced to 'different support', and most often becomes exclusion from the mainstream and/or inferior access to the regulating principles of school mathematics for 'success'. Long-term exclusion is thus deployed under the auspices of inclusive practice (Bishop \& Kalogeropoulos, 2015; Sullivan et al., 2002). Those carrying constructions of low ability/disability tend to be the most vulnerable to practices of exclusion under a banner of 'inclusion'.

Ngũgi wa Thiong'o's (1986) conception of the 'colonisation of the mind' is given particular emphasis in the context of mathematics education, especially in this subject area, one which is most associated with cognition and intellectual work (Dowling, 1998). In some instances, divisive mathematics teaching practices create a culture of regimentation and threat (Naidoo, 1999), reinforcing the colonising power of mathematics education in this mode. The colonisation of the mind acts politically to install a class-based governmentality (Foucault, 2004) that acts to reify a particular dominant global reality and reinforce the existing status quo, dividing the world (Willinsky, 1998) according to those 'who can' and those 'who can't' do mathematics. This acts inextricably with the political and psycho-sociological effect of internalisation of colonised ways of knowing achieved through a divisive mathematics education in practice. The effect of 'low ability' streaming has such a colonising affect/effect. While perceived as a state of nature, ability is often claimed to be measurable through testing, and mathematics tests are viewed as a straightforward guide of intellectual ability. William, Bartholomew and Reay (2004), however, note that what is deemed a measure of mathematical competence and intellectual ability, is often a measure of the pupil's ability to cope with the social framing of tests, thus pointing to a question of cultural capital (Bourdieu \& Wacquant, 1992). Gamoran (2004) makes reference to how low-level tracks or streams fuel a vicious cycle of low expectations in students and teachers. Teachers learn to have low expectations of certain pupils, especially disadvantaged and/or low achieving ones, and assign them slower-paced or more fragmented, procedural forms of instruction. This then causes pupils to adjust their expectations and efforts, which results in even lower achievement levels. Bishop and Kalogeropoulos (2015) speak of learning difficulties associated with the effect of labelling pupils as having 'low ability'. If labelled a 'slow learner', this gives credence to the 'need' for ASN, giving way to the acceptance of exclusion from the mainstream classroom (Sullivan et al., 2002). The result is that this then becomes a normalised state of affairs.

Mathematics education in this tenor installs a class mechanism into schooling practices as an "occupation of the mind" (Khuzwayo, 1998). Learning your place in the world, as a taken-for-granted socialisation of mathematics education, helps to legitimise the 'weeding out' or 'gatekeeping role' (Davis, 2013) mathematics and mathematics education serves in society, and thus ensures acceptance of the status quo as a divided world. The naturalised division of the world through mathematics education practices is premised on a logic of intellectual 'ability', often disguising classism, racism, gender discrimination, and other forms of prejudice (Dowling, 1998; Swanson, 2004, 2005).

\section{Mathematics Education, Inclusion, and the Law}

Practices of socially constructing ability in mathematics education have often seen 'included' children being socially excluded from their peers. While local education authorities (LEAs) are often unaware of these practices within schools, or may even endorse them through the way they may fit with their interpretations of inclusion, a child's right to inclusion in education can be breached by measures implementing procedural justice set by the LEAs. It can be argued that the 'included' learners would likely suffer substantive injustice as a result. Examples span those related to streaming/tracking or 'ability grouping', often based on teachers' perceptions of a pupil's ability. It is as if such 'knowledge' of the pupil were a straightforward revelation of 'fact' about that pupil. This 'knowledge' of the pupil then becomes naturalised in the context of the school and schooling relations. This works between the epistemic and the ontological spheres, giving rise to a way of 'knowing' a pupil becoming foundational to their existence. It gives justification to segregation in the school, notably the assigning of different classrooms for different 'ability groups', based on an indelible construction of a notion of ability. Or, in the case of perceived 'disability', the practice is ubiquitous of removing the pupil from the mainstream class (often to a 'special' classroom space referred to as 'the Base' in the Scottish secondary school context), where they may be exposed to a reduced, inferior learning experience under an assumption of ASN accommodations. This then prevents them from access to the same mainstream learning experiences of their peers. Such exclusion in the application of method of inclusion would directly deny the pupils' rights to inclusion in education under article 2 of the First Protocol to the European Convention on Human Rights on children's rights to education. Furthermore, parents often have little say in state schools as to how their child is being grouped, the criteria being applied for such decisions, and to which classroom and context of learning their child is being assigned. This may breach the state's duties in respecting "the right of parents to ensure such education and teaching (is) in conformity with their own religious and philosophical convictions" (United Nations, Office of the High Commissioner on Human Rights, 1989) under the same provision.

While it occurs extensively across Scottish secondary schools, Hamilton and O'Hara (2011) make note of the 
increasing application of streaming or setting in Scottish primary schools. Whetton and Twist (2003) recognise that Scottish primary schools are more likely to use ability grouping than any other grouping system in their classrooms. While it is noteworthy that any form of ability grouping would act as a form of social organisation that promotes inequity and segregation (Ireson \& Hallam, 2001), its use in Scottish schooling acts as a contradiction to the avowed stance on equal education as extolled in the national curriculum, CfE. This has implications for inclusion and child rights to equal education, not only as avowed but as practiced.

In Scotland, the legal framework requires the LEAs action in providing inclusion as seen in article 12 of the United Nations Convention on the Rights of the Child; the Human Rights Act 1998; the Scotland Act; Education (Scotland) Act 2016; Standards in Scotland's Schools etc. Act 2000; Scottish Schools (Parental Involvement) Act 2006; and Education (ASL) (Scotland) Act 2004. In the case of $X$ (minors) v Bedfordshire County Council [1995], the House of Lords condemned the LEA's breach of common law duty constituting negligence in failing to take appropriate actions to assess or diagnose children's learning difficulties in order to provide appropriate educational assistance. This case set the precedence for the current law and its inclusion protections in the UK.

In the implementation of inclusion, the viewpoints of pupils, parents and LEAs are required. The importance of children's own views is provided in article 12 of the United Nation Convention on the Rights of the Child. Decision-making adults are encouraged to listen to the opinion of children and involve them in decision-making. The need to respect children's views effectively corresponds with section 12 of the Human Rights Act 1998 on freedom of expression. Section 12 gives effect to article 10 of the Human Rights Directives on individual rights to hold opinions and receive and impart information and ideas without interference by public authority and regardless of frontiers.

The reading of article 8 of the Convention suggests that the viewpoints of pupils and parents in the name of right to private and family life to be the principle consideration in implementing the inclusion policy on the school level. The Children and Young People (Scotland) Act 2014 is designed to put 'families and children at the centre' of all decisions that affect children and young people in Scotland. Further, one of the aims of the Scottish government policy, Getting It Right For Every Child (GIRFEC), is centred on inclusion of the voice of children and families (Scottish Government, 2008).

The Education (Additional Support for Learning) (Scotland) Act 2004 articulates duties to Local Authorities and other agencies for the provision of additional support where needed, but in respect of additional intervention, the responsibility is expected to start with the class teacher who is required to follow a specific sequence of procedures and processes, such as GIRFEC, if this becomes necessary. This is applying what is referred to as a 'multi-agency approach'. Following this approach, children and families are to be directly involved in the decision-making process about what affects those children and young people. However, research into educational inclusive policy and practice in the Scottish schooling context seems to suggest otherwise (Mouroutsou, 2017). In practice, it seems that some school teachers and LEAs take the leading role in setting the measures and determining 'the barrier' as well as deciding on the issue of inclusion. Consequently, pupils and parents often have little to no input in decision-making. Against such a backdrop, current practices seem to overlook the legal requirements by teachers and LEAs. The issue of privacy is also breached in many instances, where teachers make individual accommodations, set separate tasks, or have 'inclusive' learners leave the classroom at various junctures in the school day. This is done openly in front of peers, so the right to privacy is thus one frequently breached in classrooms. The mathematics classroom is very often the place where practices of exception, i.e. exclusionary practices, frequently occur (Bishop \& Kalogeropoulos, 2015; Jörgensen et al., 2014; Sullivan et al., 2002; Swanson, 2005). Prevalent examples are those of classrooms segregated according to 'ability grouping' where demarcations are highly visible, or where a learner is asked to leave the classroom and attend a support needs 'Base', thereby openly 'marking' bodies through the 'marking' of minds.

Children's right to express their views on arrangements that involve them was provided in article 12 of the United Nations Convention on the Rights of the Child on the international level; and in article 10(1) of the Human Rights Act 1998 in the UK. In Scotland, any decision that may affect the child or young person, due regard to that child or young person's view must be paid in accordance with section 2(2) of the Standards in Scotland's Schools etc. Act 2000 and section 4 of the Education (Scotland) Act 2016. Article 23 of the United Nations Convention on the Rights of the Child requires governments to recognise children's right to enjoy a full and respectful life in the context of social integration. This is clearly articulated in the words:

...children are given the right to education in a manner conducive to the child's achieving the fullest possible social integration and individual development, including his or her cultural and spiritual development. (United Nations, Office of the High Commissioner on Human Rights, 1989)

This corresponds with the right to education in article 2 of the first protocol of the Human Rights Act 1998. Specifically, this right is linked to the public authority's duty to respect the right of parents to ensure that the education and teaching provided by the LEAs is in conformity with their own religious and philosophical convictions. Similar tone is also observed in section 1 of the Standards in Scotland's Schools etc. Act 2000, which guarantees that 
every child of school age shall be provided with school education or other arrangement by an education authority. The word 'shall' used in section 2(1) of the Act must be interpreted as a statutory duty of the education authority to do so.

Taking the right to education and LEAs' duty on board, it is not only fundamentally important for education law to address this need, but also to prevent 'included' children from being marginalised and discriminated against, by reason only of the difference determined by the barriers set by the LEAs. In the context of integration for the disabled, the Snowdon working party (ThorpeTracey, 1976) used the term "absence of the segregation" and "social acceptance", yet segregation and social exclusion is often widely instituted in schools. This is done through practices of determination by excluding certain pupils from the mainstream mathematic class, away from their peers, and offering a different replacement to their learning.

\section{Conclusions}

School mathematics discourse and practice is hierarchical as a consequence of mathematics' 'strong voice' in schools and society. This is reflected in the increasing policy and curricular emphasis on 'numeracy' and STEM in Scotland, but also as a widening trend in the international arena. School mathematics is therefore invested in power relations, thereby (re)producing a social class structure that affords access and opportunity to some and not others, based on constructions of ability and disadvantage. Practices of inclusion are framed by relations of power that operate within classroom mathematics discourses and practices in complex ways that often enable and effect exclusion. These issues are ones of ethics, democracy and equality in the politics of meaning in mathematics education, but are also an issue of lawfulness in accordance with rights-based approaches to practices in mathematics classrooms.

It can be argued that removing a child from the learning environment comprised of their peers, or publicly treating a child differently based on constructions of 'low ability' or 'disability' or some form of difference-asdeficit, would have negative social, cognitive and psychological impact on the child into adulthood. This is because depriving the children's right to learn with their peers in the mainstream classroom can be seen as an exclusion measure, which may lead to social deprivation in the school setting with potential further cognitive/psychological impact. Often, LEA's interpretations of their legal obligations and the provisions in place in the secondary school, seems to use 'different from' as a 'get-out clause' rather than 'additional to'. This prevents provision of meaningful education to the 'included' learners who are constructed as mathematically disabled and/or kept out of their peers' class and often directed to a replacement class with mostly low attainment learning outcomes.
Practices have lagged policy, and this has implications for research. A greater emphasis is needed on researching disadvantage in mathematics classrooms by taking into account a rights-based approach to issues that emerge beyond arriving at ethics or inequality in and of themselves, even as these are critically important. This meets social justice aims more substantively. Socially-just mathematics education in schools requires embracing greater legal tenure in policy, practice and research discussions on inclusion in ways that centralise a rights-based approach. There are also implications for professionalism in schools, with policy-makers, LEAs and teachers potentially needing to better understand the consequences of exclusionary practices and what these may look like, from a legal framework, a policy perspective, and pedagogically. This advocacy is not with the intention of demonising teachers or contributing to widespread discourses on 'teacher blame', but to rather draw attention to the deeply unequal and divisive structural conditions that may lead teachers and schools in specific contexts to make particular choices that effect participation in practices of exclusion under a decree of 'inclusion'. It is the specific enabling conditions for exclusion and inequality, and the relations of power that produce them, which is the focus of attention here, taking on rightsbased and justice-oriented perspectives.

More importantly, there is a need for national and transnational conversations, from both critical sociological and rights-based approaches, on systemic exclusions and injustice performed through schooling systems in Scotland and world-wide. These conversations need to include critical debate on the social systems that feed and support hierarchical, class-based and unequal schooling systems. They should also include a return to public debate on the purposes of Education, and especially mathematics education, which often performs such injustices and divisions powerfully and under a veil of espoused political neutrality. There also needs to be greater inclusion of voice of children and young people in the decision-making of their lives and educational futures. Certainly, rights-based perspectives would necessitate such advocacy. How to achieve an inclusive, socially-just mathematics education in schools in international context is becoming an increasing imperative in the light of widening inequalities and polarisations globally. In response, mathematics education has a political and legal responsibility to address such undemocratic trends and increasing exclusions in schools and society.

\section{Conflict of Interests}

The authors declare no conflict of interests.

\section{References}

Allan, J. (2003). Daring to think otherwise? Educational policymaking in the new Scottish Parliament. Journal of Educational Policy, 18(3), 289-301. 
Allan, J. (2008) Inclusion for all? In T. G. K. Bryce \& W. M. Humes (Eds.), Scottish education: Beyond devolution (pp. 701-710). Edinburgh: Edinburgh University Press.

Althusser, L. (1971). Ideology and the ideological state apparatus: Notes towards an Investigation. London: Verso.

Atweh, B., Forgasz, H., \& Nebres, B. (2001). Sociocultural research on mathematics education: An international perspective. Mahwah: Lawrence Erlbaum Associates.

Atweh, B., Rossi Becker, J., Grevholm, B., \& Subramanian, J. (2016). A discussion paper on the state of research on equity in mathematics education and arising challenges. Topic Group 33, Equity in Mathematics Education. Paper presented at the 13th International Congress of Mathematics Education, 24-31 July 2016, University of Hamburg, Germany.

Atweh, B., \& Swanson, D.M. (2016). Alternative understandings of equity and their relationship to ethics. Paper presented at the 13th International Congress of Mathematics Education, 24-31 July 2016, University of Hamburg, Germany.

Bernstein, B. (2000). Pedagogy, symbolic control, and identity: Theory, research, critique (revised). New York: Rowman \& Littlefield Publishers.

Bishop, A. J. (2008). Values in mathematics and science education: Similarities and differences. The Mathematics Enthusiast, 5(1), 47-58.

Bishop, A. J., \& Kalogeropoulos, P. (2015). (Dis)engagement and exclusion in mathematics classroomsValues, labelling and stereotyping. In A. Bishop, T. Hazel, \& T. Barkatsas (Eds.), Diversity in mathematics education: Towards inclusive practices (pp. 193-217). Dordrecht: Springer.

Bourdieu, P., \& Wacquant, L. J. D. (1992). An invitation to a reflexive sociology. Chicago: University of Chicago Press.

Children and Young People (Scotland) Act 2014. London: UK Government. Retrieved from http:// www.legislation.gov.uk/asp/2014/8/contents/enacted

Chronaki, A., \& Swanson, D. M. (2017). De/mathematising the political: Bringing feminist de/postcoloniality to mathematics education. Plenary presented at the 69th conference of the International Commission for the Improvement and Study of Mathematics Teaching (CIEAEM69), 15-19 July 2017, Freie Universität, Berlin.

Collins, F. S. (2006). The language of God: A scientist presents evidence for belief. New York: Free Press.

Davis, B. (2013). Teaching mathematics: Toward a sound alternative. London: Routledge.

Davis, J. D., \& Hersh, R. (1986). Mathematics and imposed reality. In P. J. Davis, \& R. Hersh (2005), Descartes' dream: The world according to mathematics. Boston: Houghton Mifflin.

Dengate, B., \& Lerman, S. (1995). Learning theory in mathematics education: Using the wide-angle lens and not just the microscope. Mathematics Education Research Journal, 7(1), 26-36.

Department of Education and Science. (1978). Report of the committee of inquiry into the special educational needs of children and young people ('Warnock Report'). London: DES.

Dowling, P. C. (1991). A touch of class: Ability, social class and intertext in SMP 11-16. In D. Pimm \& E. Love, (Eds.), Teaching and learning school mathematics. London: Hodder and Stoughton.

Dowling, P. (1998). The sociology of mathematics education: Mathematical myths, pedagogic texts. London and Washington: Falmer Press.

Ernest, P., Sriraman, B., \& Ernest, N. (2016). (Eds.). Critical mathematics education: Theory, praxis and reality. Charlotte: IAP.

Equality Act. 2010. London: HMSO. Retrieved from http://www.legislation.gov.uk/ukpga/2010/15/pdfs/ ukpga_20100015_en.pdf

Ferguson, J., \& Gupta, A. (2002). Spatializing states: Towards an ethnography of neoliberal governmentality. American Ethnologist, 29(4), 981-1002.

Figueiras, L., Healy, L., \& Skovsmose, O. (2016). Difference, inclusion, and mathematics education: Launching a research agenda. International Journal for Studies in Mathematics Education, 9(3), 15-35.

Foucault, M. (2004). Governmentality. In J. D. Faubian (Ed.), Michel Foucault: Power, essential works of Foucault 1854-1984. London: Penguin.

Gamoran, A. (2004). Classroom organization and instructional quality. In M. Wang \& J. Walberg (Eds.), Can unlike students learn together? Grade retention, tracking, and grouping (pp. 141-155). Greenwich: Information Age.

Gates, P., \& Jörgensen, R. J. (2009). Foregrounding social justice in mathematics teacher education. Journal of Mathematics Teacher Education, 12(3), 161-170.

Gellert, U., \& Jablonka, E. (2007). (Eds.). Mathematisation and demathematisation: Social, philosophical and educational ramifications. Rotterdam: Sense.

Goodley, D. (2004). Who is disabled? Exploring the scope of the social model of disability. In J. Swain, S. French, C. Barnes, \& C. Thomas (Eds.), Disabling barriers: Enabling environments. London: SAGE.

Goodley, D. (2013). Dis/entangling critical disability studies. Disability \& Society, 28(5), 631-644. doi:10.1080/ 09687599.2012 .717884

Gutstein, E. (2006). Reading and writing the world with mathematics: Toward a pedagogy for social justice. New York: Routledge.

Hamilton, L., \& O'Hara, P. (2011). The tyranny of setting (ability grouping): Challenges to inclusion in Scottish primary schools. Teaching and Teacher Education, 27(4), 712-721.

Harwood, V., \& Allan, J. (2014). Psychopathology at school: Theorizing mental disorders in education. London: Routledge.

Human Rights Act 1998. Retrieved from https://www. 
legislation.gov.uk/ukpga/1998/42/pdfs/ukpga_1998 0042_en.pdf

Ireson, J., \& Hallam, S. (2001). Ability grouping in education. London: SAGE.

Jörgensen, R., Gates, P., \& Roper, V. (2014). Structural exclusion through school mathematics: Using Bourdieu to understand mathematics as a social practice. Educational Studies in Mathematics, 87, 221-239.

Khuzwayo, H. (1998). Occupation of our minds: A dominant feature in mathematics education in South Africa. In P. Gates (Ed.), Proceedings of the first International Mathematics Education and Society Conference (pp. 219-232). Nottingham: Centre for the Study of Mathematics Education, Nottingham University.

Larner, W. (2000). Neo-liberalism: Policy, ideology, governmentality. Studies in Political Economy, 63, 5-25.

Lemke, T. (2001). 'The birth of bio-politics': Michel Foucault's lecture at the Collège de France on neo-liberal governmentality. Economy and Society, 30(2), 190. doi:10.1080/713766674

Lubienski, S. T., \& Lubienski C. (2005). A new look at public and private schools: Student background and mathematics achievement. Phi Delta Kappan, 86(9), 696-699.

Maheux, J., Swanson, D. M., \& Khan, S. (2012). From text to pretext: An Ethical turn in curriculum work. In T. C. Mason \& R. J. Helfenbein (Eds.), Ethics and international curriculum work: The challenges of culture and context (pp. 143-172). Charlotte: IAP.

Mouroutsou, S. (2017). Policy implementation in inclusive education: A complexity perspective (Doctoral dissertation). University of Glasgow.

Naidoo, A. (1999). The impact of the experiences of novice teachers on the mathematics curriculum at a South African college of education (Unpublished doctoral dissertation). Aalborg University Centre and Royal Danish School of Educational Studies, Aalborg and Copenhagen.

National Foundation For Educational Research. (2016). NFER education briefings: Key insights from PISA 2015 (Scotland). Retrieved from https:// www.nfer.ac.uk/publications/99959/99959.pdf

OECD. (2016). Education at a glance 2016: OECD indicators. Paris: OECD Publishing.

Perry, L., \& McConney, A. (2010). Does the SES of the school matter? An examination of socioeconomic status and student achievement using PISA 2003. Teachers College Record, 112(4), 1137-1162.

Rancière, J. (2009). The method of equality: An answer to some questions. In G. Rockhill, \& P. Watts (Eds.), Jacques Rancière: History, politics, aesthetics (pp. 273-788). Durham: Duke University Press.

Riddell, S. (2009). Social justice, equality and inclusion in Scottish education. Discourse, 30(3), 283-297.

Scottish Government. (2008). A guide to getting it right for every child. Retrieved from http://www.gov.scot/ Resource/0045/00458341.pdf

Scottish Government. (2016). Programme for Inter- national Student Assessment (PISA) 2015: Highlights from Scotland's results. Retrieved from http:// www.gov.scot/Resource/0051/00511095.pdf

Skovsmose, O. (1994). Towards a philosophy of critical mathematics education. Dordrecht: Kluwer.

Skovsmose, O., \& Valero, P. (2001). Breaking political neutrality: The critical engagement of mathematics education with democracy. In B. Atweh, H. Forgasz, \& B. Nebres (Eds.), Sociocultural research on mathematics education: An international perspective (pp. 37-55). New Jersey: Erlbaum.

Skovsmose, O., \& Yasukawa, K. (2004). Formatting power of "mathematics in a package": A challenge for social theorising? Philosophy of Mathematics Education Journal, 18.

Standards in Scotland's Schools etc. (Scotland) Act 2000. Retrieved from http://www.legislation.gov.uk/ asp/2000/6/introduction

Stinson, D. (2017, July). In search of defining ethics in (mathematics) education research? Journal of Urban Mathematics Education, 10(1), 1-6.

Sullivan, P., Zevenbergen, R., \& Mousley, J. (2002). Contexts in mathematics teaching: Snakes or ladders? In B. Barton, K. C. Irwin, M. Pfannkuch, \& M. Thomas (Eds.), Mathematics education in the South Pacific (pp. 649-656). Sydney: MERGA.

Swanson, D. M. (1998). Bridging the boundaries? A study of mainstream mathematics, academic support and "disadvantaged learners" in an independent, secondary school in the Western Cape (South Africa). University of Cape Town.

Swanson, D. M. (2004). Voices in the silence: Narratives of disadvantage, social context, and school mathematics in post-apartheid South Africa (Doctoral dissertation). University of British Columbia.

Swanson, D. M. (2005). School mathematics: Discourse and the politics of context. In A. Chronaki \& I. M. Christiansen (Eds.), Challenging perspectives on mathematics classroom communication. International perspectives on mathematics education: cognition, equity \& society (pp. 261-294). Greenwich: IAP.

Swanson D. M. (2013). Neoliberalism, education and citizenship rights of unemployed youth in postapartheid South Africa. Sisyphus: Journal of Education, 1(2), 194-212.

Swanson, D. M. (2017). Mathematics education and the problem of political forgetting. In search of research methodologies for global crisis. Journal of Urban Mathematics Education, 10(1), 7-15.

Swanson, D. M., \& Appelbaum, P. (2012). Refusal as a democratic catalyst for mathematics education development. Pythagoras, 33(2).

Tagg, J. (1988). The burden of representation: Essays on photographies and histories. Basingstoke: Macmillan.

Thorpe-Tracey, R. (1976). Integrating the disabled: Report of the Snowdon working party. Working Party on Integration of the Disabled. 
Tytler, R., Swanson, D. M., \& Appelbaum, P. (2015). Subject matters of science, technology, engineering, and mathematics. In M. F. He, B. D. Schultz, W. H. Schubert (Eds.), The SAGE guide to curriculum in education (pp. 27-35). Los Angeles: SAGE.

UNESCO. (1994). The Salamanca statement and framework for action on special needs education. Paris: UNESCO. Retrieved from http://unesdoc.unesco.org/ images/0009/000984/098427eo.pdf

United Nations, Office of the High Commissioner on Human Rights. (1989). Convention on the rights of the child. Retrieved from http://www.ohchr.org/EN/ Professionallnterest/Pages/CRC.aspx

Valero, P., \& Zevenbergen, R. (2004). Researching the socio-political dimensions of mathematics education: Issues of power in theory and methodology. Dordrecht: Kluwer.

Valle, J. W., \& Connor, D. J. (2010). Rethinking disability: A disability studies approach to inclusive practices. New York: McGraw-Hill.

Vithal, R. (2010). Democratising mathematics educational doctoral research teaching and learning: Undoing the North-South divide. In H. Alro, O. Ravn, \& P. Valero (Eds.), Critical mathematics education: Past, present, and future. Rotterdam: Sense Pub.

wa Thiong'o, N. (1986). Writing against neo-colonialism. London: Vita Books.

Walkerdine, W. (2012). Counting girls out: Girls and mathematics. London: UK Falmer Press.
Watson, N. (2012). Theorising the lives of disabled children; How can disability theory help? Children \& Society, 26(3), 192-202.

Whetton, C., \& Twist, L. (2003). What determines the range of reading attainment in a country? Presented at the $29^{\text {th }}$ International Association for Educational Assessment Conference, Manchester, UK.

William, D., Bartholomew, H., \& Reay, D. (2004). Assessment, learning and identity. In P. Valero \& R. Zevenbergen (Eds.), Researching the socio-political dimensions of mathematics education: Issues of power in theory and methodology (pp. 43-62). Dordrecht: Kluwer.

Willinsky, J. (1998). Learning to divide the world: Education at empire's end. Minneapolis, MN: University of Minnesota Press.

$X$ (minors) v Bedfordshire County Council [1995] 3 All ER 353.

Zevenbergen, R. (2001). Language, social class and underachievement in school mathematics. In P. Gates (Ed.), Issues in mathematics teaching (pp. 38-50). London: RoutledgeFalmer.

Zevenbergen, R. (2003). Teachers' beliefs about teaching mathematics to students from sociallydisadvantaged backgrounds: Implications for social justice. In L. Burton (Ed.), Which way social justice in mathematics education? (pp. 133-151). Westport and London: Praeger.

\section{About the Authors}

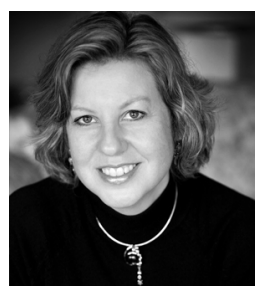

Dalene M. Swanson (PhD) is a senior academic at the University of Stirling and Adjunct Professor at the University of Alberta. She is on the international board of the UNESCO Chair in Democracy, Global Citizenship, and Transformative Education, and is an associate of the Scottish Centre for Crime and Justice Research. Dalene's research focuses on critical socio-political perspectives, and she has researched on the 'construction of disadvantage' in and through school mathematics, attending to intersectional social difference discourses. More details at: https://rms.stir.ac.uk/converis-stirling/person/23287

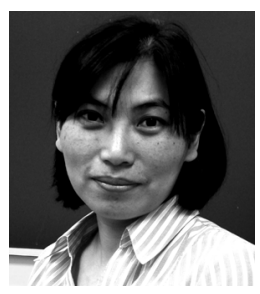

Hong-Lin Yu (PhD) is a Reader in Law at the University of Stirling. Her main areas of research are dispute resolution. She has a particular interest in exploring law in the context of current developments in practice. She also has an interest in the research areas of access to Justice and Education and Law.

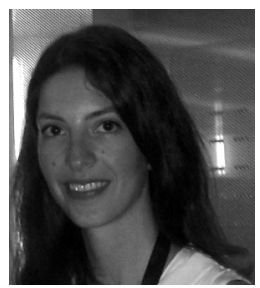

Stella Mouroutsou (PhD) is a lecturer in Education at the University of Stirling. She is particularly interested in inclusive education and education policy. She completed her PhD within the School of Education, University of Glasgow, and her doctoral research explored policy enactment in the field of inclusive education from a complexity perspective. 